\title{
Pengaruh Kombinasi Jenis Pupuk Kandang dan Tingkat Kehalusan Zeolite pada Pertumbuhan Bibit Kakao (Theobroma cacao L.)
}

\section{(The Influence of Combination of Types of Enclosure Fertilizer and the Level of Zeolite Smoothness in the Growth of Cocoa Seeds [Theobroma cacao L.])}

\author{
Ayu Mega Parama1), Rijadi Subiantoro ${ }^{2 *}$, Fatahillah ${ }^{2)}$ \\ 1) Program Studi Produksi dan Manajemen Industri Perkebunan, Politeknik Negeri Lampung Jl. \\ Soekarno-Hatta No.10 Rajabasa, Bandar Lampung, 35144, Telp.: (0721) 703995, Fax.: (0721) \\ 787309 dan 2) Jurusan Budidaya Tanaman Perkebunan, Politeknik Negeri Lampung Jl. \\ Soekarno-Hatta No.10 Rajabasa, Bandar Lampung, 35144, Telp.: (0721) 703995, Fax.: (0721) \\ 787309 \\ E-mail: rijadisubiantoro@polinela.ac.id
}

\begin{abstract}
Providing manure can not only increase the availability of nutrients but also support the growth of microorganisms. Zeolite has a high CEC, which results in the media being able to bind water and nutrients added to the soil. This study aims to get the best type of manure on cocoa seedling growth, get the effect of zeolite smoothness on the growth of cocoa seedlings, and find out the interaction of the composition of manure and zeolite on the growth of cocoa seedlings. The research was conducted at Experimental Garden of Politeknik Negeri Lampung, from December 2017 to May 2018. The method used was the factorial pattern randomized block design (RBD) which consisted of two factors. The first factor consists of three levels, namely without manure, $200 \mathrm{~g}$ chicken manure, and $200 \mathrm{~g}$ goat manure. The second factor consisted of three levels, namely zeolite size (without zeolite, zeolite size 30 mesh, and zeolite size 16 mesh). Observation variables were plant height, leaves number, stem diameter, shoot dry weight, soil pH, and soil CEC. The results showed that manure did not show an effect on plant height, stem diameter, and leaves number, but had an effect on soil $\mathrm{pH}$ and soil CEC. The level of zeolite smoothness does not affect plant height, stem diameter, leaves number, and soil $\mathrm{pH}$, but affects soil CEC the 16 mesh size of compared to 30 mesh size. There is no interaction on types of manure and size of zeolite fineness of plant height, stem diameter, leaves number, shoot dry weight, soil soil $\mathrm{pH}$, and soil $\mathrm{CEC}$.
\end{abstract}

Key words: chicken manure, cocoa, goat manure, zeolite

DOI: http://dx.doi.org/10.25181/jaip.v8i1.1053

Diterima: 11 Maret 2019 / Disetujui: 7 Oktober 2019 / Diterbitkan: 9 Mei 2020

\section{PENDAHULUAN}

Dalam upaya peningkatan produktivitas kakao, salah satu program yang harus dilakukan adalah melakukan peremajaan terhadap tanaman kakao tua maupun tanaman yang tidak produktif, yakni dengan memakai bahan tanam unggul (Wahyudi \& Rahardjo, 2008). Bahan pembenah tanah yang akan digunakan yaitu zeolite. Zeolite memiliki KPK (kapasitas pertukaran kation) yang tinggi 
(Dariah, 2007). Hal ini mengakibatkan media mampu mengikat air dan unsur hara dan melepaskan saat diperlukan tanaman. Zeolite dapat menangkap sementara hara pupuk sehingga tidak hilang tercuci dan akan dilepaskan kembali untuk diserap akar tanaman. Zeolite berperan untuk menahan sementara unsur hara di daerah perakaran, sehingga pupuk Urea dan $\mathrm{KCl}$ yang diberikan lebih efisien (Juarsah, 2016).

Pupuk kandang ayam dapat meningkatkan bahan organik tanah dan kandungan $\mathrm{C} / \mathrm{N}$ tanah, meningkatkan $\mathrm{pH}$ tanah dan memiliki kandungan unsur hara $\mathrm{N}$ dan $\mathrm{P}$ yang lebih tinggi dibandingkan pupuk kandang lainnya. Pupuk kandang ayam yang diambil dari peternakan ayam yang telah dianalisis dengan hasil analisis kandungan unsur hara $\mathrm{N}$ total, $\mathrm{P}_{2} \mathrm{O} 5, \mathrm{~K} 2 \mathrm{O}$ berturut-turut sebesar 1,72\%, 14,85\%, 6,34\% diharapkan dapat memperbaiki sifat-sifat kimia tanah Inceptisol Kwala Bekala dan meningkatkan pertumbuhan tanaman jagung (Purba et al., 2017).

Pupuk kandang kambing mempunyai sifat memperbaiki aerasi tanah, menambah kemampuan tanah menahan unsur hara, meningkatkan kapasitas menahan air, meningkatkan daya sangga tanah, sumber energy bagi mikroorganisme tanah dan sebagai sumber unsur hara. Pupuk kandang kambing mengandung unsur $\mathrm{N}$ yang dapat mendorong pertumbuhan organ - organ yang berkaitan dengan fotosintesis yaitu daun (Subhan, 2005; Rizwan, 2008). Penelitian ini bertujuan untuk mendapatkan jenis pupuk kandang yang terbaik dan pengaruh tingkat kehalusan zeolite pada pertumbuhan bibit kakao $21 \mathrm{MST}$, mengetahui interaksi komposisi pupuk kandang dan zeolite pada pertumbuhan bibit kakao.

\section{METODE PENELITIAN}

Penelitian dilaksanakan di Kebun Percobaan Politeknik Negeri Lampung pada Desember 2017 sampai dengan Mei 2018. Alat yang digunakan adalah cangkul, ayakan, penggaris, jangka sorong, pH meter, neraca O'haous, golok dan gergaji, meteran, timbangan, timbangan analitik, labu pemisah, erlenmeyer, tabung reaksi, pipet tetes, cawan, oven, dan alat tulis pencatat data. Bahan yang digunakan adalah benih kakao klon MCC.02, polibeg ukuran 20x30 cm, pasir sebagai media tanam dipersemaian, tanah topsoil, zeolite, pupuk kandang ayam, pupuk kandang kambing, bambu, paranet, dan air. Penelitian dilaksanakan menggunakan Rancangan Acak Kelompok (RAK) pola Faktorial dan diulang sebanyak tiga kali sehingga terdapat 27 satuan percobaan. Setiap perlakuan terdiri dari 3 polibag sehingga terdapat 81 polibeg. Faktor pertama adalah jenis pupuk kandang yang terdiri atas tiga taraf yaitu $\mathrm{A}_{0}$ : tanpa pupuk kandang $+3.000 \mathrm{~g}$ tanah topsoil, $\mathrm{A}_{1}: 200 \mathrm{~g}$ pupuk kandang ayam $+3.000 \mathrm{~g}$ tanah topsoil, dan $\mathrm{A}_{2}: 200 \mathrm{~g}$ pupuk kandang kambing $+3.000 \mathrm{~g}$ tanah topsoil. Faktor kedua adalah ukuran (tingkat kehalusan) zeolite yang terdiri atas tiga taraf yaitu $\mathrm{Z}_{0}$ : tanpa zeolite, $\mathrm{Z}_{1}$ : 13 g.polibeg ${ }^{-1}$ zeolite dengan ukuran 30 mesh dan $\mathrm{Z}_{2}$ : 13 g.polibeg ${ }^{-1}$ zeolite dengan ukuran 16 mesh. Variabel pengamatan yang diamati adalah tinggi tanaman, jumlah daun, diameter batang, bobot kering brangkasan, $\mathrm{pH}$ tanah setelah penelitian, dan KTK tanah setelah 
penelitian. Data yang diperoleh diuji dengan sidik ragam. Apabila nilai $\mathrm{F}$ hitung yang diperoleh berbeda nyata, pengujian dilanjutkan dengan uji beda nyata terkecil (BNT) taraf nyata $5 \%$.

\section{HASIL DAN PEMBAHASAN}

\section{Pengaruh Pupuk Kandang dan Ukuran Zeolite pada Tinggi Tanaman}

Hasil sidik ragam, kombinasi pupuk kandang dan ukuran kehalusan zeolite tidak menunjukkan pengaruh terhadap tinggi tanaman pada umur 21 minggu setelah tanam, hal ini diduga karena tidak meratanya penyinaran sehingga pembentukan karbohidrat tidak berlangsung baik. Sesuai dengan pernyataan Sutedjo dan Kartasapoetra (1990), ketersediaan unsur Nitrogen tanah dapat menghasilkan protein, semakin tinggi pemberian Nitrogen semakin cepat pula sintesis karbohidrat yang diubah menjadi protein dan protoplasma. Peningkatan protein dalam tubuh tanaman akan meningkatkan kadar Nitrogen dalam jaringan tanaman yang digunakan dalam pertumbuhan vegetasi tanaman.

Tabel 1. Pengaruh tunggal antara pupuk kandang dan zeolite pada tinggi tanaman umur 21 MST

\begin{tabular}{lc}
\hline \multicolumn{1}{c}{ Perlakuan } & Rerata tinggi tanaman (cm) \\
\hline Pengaruh tunggal pupuk kandang & \\
$\mathrm{A}_{0}=$ tanpa pupuk kandang & $32,88 \mathrm{a}$ \\
$\mathrm{A}_{1}=200$ g pupuk kandang ayam & $33,31 \mathrm{a}$ \\
$\mathrm{A}_{2}=200$ g pupuk kandang kambing & $33,39 \mathrm{a}$ \\
\hline Pengaruh tunggal zeolite & \\
$\mathrm{Z}_{0}=$ tanpa zeolite & $33,73 \mathrm{a}$ \\
$\mathrm{Z}_{1}=13$ g zeolite dengan ukuran 30 mesh & $33,74 \mathrm{a}$ \\
$\mathrm{Z}_{2}=13$ g zeolite dengan ukuran 16 mesh & $32,66 \mathrm{a}$ \\
\hline
\end{tabular}

Keterangan: Nilai rata-rata yang diikuti oleh huruf yang sama pada kolom yang sama menunjukkan tidak berbeda nyata dengan uji BNT taraf 5\%

\section{Pengaruh Pupuk Kandang dan Ukuran Zeolite pada Diameter Batang}

Hasil sidik ragam kombinasi pupuk kandang dan ukuran tingkat kehalusan zeolite tidak menunjukkan pengaruh terhadap diameter batang. Hal ini diduga karena pada pertumbuhan bibit masih menggunakan cadangan makanan pupuk anorganik, sehingga dalam pemberian pupuk kandang (pupuk ayam dan pupuk kambing) hara $\mathrm{N}$ masih belum berdampak. Sutejo \& Kartasapoetra (1990), untuk dapat tumbuh dengan baik tanaman membutuhkan hara N, P dan K yang merupakan unsur hara esensial dimana unsur hara ini sangat berperan dalam pertumbuhan tanaman secara umum pada fase vegetatif. 
Tabel 2. Pengaruh tunggal antara pupuk kandang dan zeolite pada diameter batang umur 21 MST

\begin{tabular}{lc}
\hline \multicolumn{1}{c}{ Perlakuan } & $\begin{array}{c}\text { Rerata diameter } \\
\text { batang (cm) }\end{array}$ \\
\hline Pengaruh tunggal pupuk kandang & $0,70 \mathrm{a}$ \\
$\mathrm{A}_{0}=$ tanpa pupuk kandang & $0,72 \mathrm{a}$ \\
$\mathrm{A}_{1}=200$ g pupuk kandang ayam & $0,72 \mathrm{a}$ \\
$\mathrm{A}_{2}=200 \mathrm{~g}$ pupuk kandang kambing & \\
\hline Pengaruh tunggal zeolite & $0,69 \mathrm{a}$ \\
$\mathrm{Z}_{0}=$ tanpa zeolite & $0,70 \mathrm{a}$ \\
$\mathrm{Z}_{1}=13 \mathrm{~g}$ zeolite dengan ukuran 30 mesh & $0,73 \mathrm{a}$ \\
$\mathrm{Z}_{2}=13 \mathrm{~g}$ zeolite dengan ukuran 16 mesh & \\
\hline Keterangan: Nilai rata-rata yang diikuti oleh huruf yang sama pada kolom yang sama \\
menunjukkan tidak berbeda nyata dengan uji BNT pada taraf 5\%
\end{tabular}

\section{Pengaruh Pupuk Kandang dan Ukuran Zeolite pada Jumlah Daun}

Hasil uji sidik ragam, kombinasi pupuk kandang dan ukuran kehalusan zeolite tidak menunjukkan pengaruh terhadap jumlah daun pada umur 21 minggu setelah tanah. Hal ini diduga karena karena kurangnya air yang terjadi pada musim kemarau. Kekurangan air secara internal pada tanaman berakibat langsung pada penurunan pembelahan dan pembesaran sel. Hal ini sesuai dengan pernyataan Soemartono (1990), air sangat dibutuhkan oleh tanaman dalam semua proses fisiologis tanaman termasuk pembelahan sel dan proses pembentukan daun. Menurut Harjadi (1996), tanaman sangat membutuhkan air dalam jumlah yang teratur untuk mendukung pertumbuhannya, sehingga pemberian air yang merata sepanjang pertumbuhan tanaman akan selalu ideal untuk tanaman tersebut.

Tabel 3. Pengaruh tunggal antara pupuk kandang dan zeolite pada jumlah daun umur 21 MST

\begin{tabular}{lc}
\hline \multicolumn{1}{c}{ Perlakuan } & $\begin{array}{c}\text { Rerata jumlah daun } \\
\text { (helai) }\end{array}$ \\
\hline Pengaruh tunggal pupuk kandang & $18,00 \mathrm{a}$ \\
$\mathrm{A}_{0}=$ tanpa pupuk kandang & $18,96 \mathrm{a}$ \\
$\mathrm{A}_{1}=200$ g pupuk kandang ayam & $17,96 \mathrm{a}$ \\
$\mathrm{A}_{2}=200$ g pupuk kandang kambing & $18,50 \mathrm{a}$ \\
\hline Pengaruh tunggal zeolite & $18,43 \mathrm{a}$ \\
$\mathrm{Z}_{0}=$ tanpa zeolite & $18,12 \mathrm{a}$ \\
$\mathrm{Z}_{1}=13$ g zeolite dengan ukuran 30 mesh & \\
$\mathrm{Z}_{2}=13$ g zeolite dengan ukuran 16 mesh & \\
\hline Keterangan: Nilai rata-rata yang diikuti oleh huruf yang sama pada kolom yang sama \\
\multicolumn{2}{c}{ menunjukkan tidak berbeda nyata dengan uji BNT pada taraf 5\% }
\end{tabular}

\section{Pengaruh Pupuk Kandang dan Ukuran Zeolite pada Bobot Kering Brangkasan}

Hasil uji sidik ragam menunjukan bahwa kombinasi pupuk kandang dan ukuran tingkat kehalusan zeolite tidak menunjukkan pengaruh terhadap bobot kering brangkasan. Diduga kurangnya penyinaran cahaya matahari dalam pertumbuhan bibit tanaman. Menurut Harjadi 
(1996), adanya jarak tanam yang berbeda akan memungkinkan perbedaan iklim mikro dari suatu tanaman tetapi bila jarak tanam semakin rapat maka tanaman akan terjadi persaingan untuk mendapatkan faktor tumbuh, padahal penggunaan hara, air, dan cahaya matahari yang maksimum akan memberikan produksi yang tinggi. Terpenuhinya cahaya matahari untuk proses fotosintesis maka penimbunan asimilat dalam daun cukup meningkat. Menurut Gardner et al. (1991), bobot kering merupakan parameter pengukuran yang mencerminkan banyaknya asimilat yang dihasilkan oleh tanaman.

Tabel 4. Pengaruh tunggal antara pupuk kandang dan zeolite pada bobot brangkasan pada 21 MST

\begin{tabular}{lc}
\hline \multicolumn{1}{c}{ Perlakuan } & $\begin{array}{c}\text { Rerata bobot brangkasan } \\
\text { (gr) }\end{array}$ \\
\hline Pengaruh tunggal pupuk kandang & \\
$\mathrm{A}_{0}=$ tanpa pupuk kandang & $6,77 \mathrm{a}$ \\
$\mathrm{A}_{1}=200$ g pupuk kandang ayam & $7,01 \mathrm{a}$ \\
$\mathrm{A}_{2}=200$ g pupuk kandang kambing & $6,86 \mathrm{a}$ \\
\hline Pengaruh tunggal zeolite & $6,98 \mathrm{a}$ \\
$\mathrm{Z}_{0}=$ tanpa zeolite & $7,36 \mathrm{a}$ \\
$\mathrm{Z}_{1}=13$ g zeolite dengan ukuran 30 mesh & $6,30 \mathrm{a}$ \\
$\mathrm{Z}_{2}=13$ g zeolite dengan ukuran 16 mesh & \\
\hline Keterangan: Nilai rata-rata yang diikuti oleh huruf yang sama pada kolom yang sama \\
menunjukkan tidak berbeda nyata dengan uji BNT pada taraf 5\%
\end{tabular}

\section{Pengaruh Pupuk Kandang dan Ukuran Zeolite pada pH Tanah}

Hasil uji sidik ragam menunjukkan bahwa terdapat pengaruh pada perlakuan pupuk kandang, tetapi tidak berpengaruh pada perlakuan zeolite dan interaksi di antara keduanya. Pengaruh tunggal pupuk kandang dan zeolite $\mathrm{pH}$ tanah dilihat pada Tabel 5.

Tabel 5. Pengaruh tunggal antara pupuk kandang dan zeolite pada $\mathrm{pH}$ tanah

\begin{tabular}{lc}
\hline \multicolumn{1}{c}{ Perlakuan } & Rerata $\mathrm{pH}$ tanah \\
\hline Pengaruh tunggal pupuk kandang & \\
$\mathrm{A}_{0}=$ tanpa pupuk kandang & $5,27 \mathrm{~b}$ \\
$\mathrm{~A}_{1}=200$ g pupuk kandang ayam & $6,11 \mathrm{a}$ \\
$\mathrm{A}_{2}=200$ g pupuk kandang kambing & $6,09 \mathrm{a}$ \\
$\mathrm{BNT}=0,18$ & \\
\hline Pengaruh tunggal zeolite & \\
$\mathrm{Z}_{0}=$ tanpa zeolite & $5,84 \mathrm{a}$ \\
$\mathrm{Z}_{1}=13$ g zeolite dengan ukuran 30 mesh & $5,81 \mathrm{a}$ \\
$\mathrm{Z}_{2}=13$ g zeolite dengan ukuran 16 mesh & $5,80 \mathrm{a}$ \\
\hline
\end{tabular}

Keterangan: Angka yang diikuti dengan huruf yang berbeda pada kolom dan baris yang sama menunjukkan berbeda nyata berdasarkan uji BNT pada taraf 5\%

Berdasarkan Tabel 6 menunjukkan bahwa dalam penambahan zeolite tidak berpengaruh terhadap peningkatan nilai $\mathrm{pH}$ tanah, namun peningkatan $\mathrm{pH}$ tanah hanya terjadi pada perlakuan 
pupuk kandang. Hal ini diduga karena zeolite memilik pH netral dan tercucinya unsur hara pada tanah akibat curah hujan, ketika terjadinya erosi tanah maka unsur hara yang dibutuhkan tanaman dalam tanah dapat ikut hanyut oleh air. Unsur hara yang rendah di dalam tanah dapat menyebabkan tingginya tingkat keasaman tanah, sehingga $\mathrm{pH}$ tanah menjadi masam. Dengan demikian menyebabkan zeolite menjadi masam dan tidak mempengaruhi perubahan $\mathrm{pH}$ pada bahan tanah yang ditambahkan (Suwardi, 2002). Menurut Pujiastuti \& Erwan (2007), zeolite mempunyai sifat khas yang diakibatkan oleh struktur dan komposisi kimianya antara lain yang bersifat masam yang diakibatkan oleh pergantian kation penetral dengan proton akan menimbulkan pusat asam bronstead.

\section{Pengaruh Pupuk Kandang dan Ukuran Zeolite pada Kapasitas Tukar Kation (KTK)}

Hasil sidik ragam menunjukan bahwa perlakuan kombinasi pupuk kandang dan ukuran zeolite menunjukkan pengaruh terhadap KTK tanah, namun tidak berpengaruh terhadap interaksi diantara keduanya. Diduga karena zeolite dapat mengikat sementara hara pupuk, sehingga terhindar dari pencucian dan akan dilepaskan kembali untuk diserap akar tanaman. Hal ini juga ditegaskan oleh Juarsah (2016), zeolite berperan untuk menahan sementara unsur hara di daerah perakaran, sehingga pupuk Urea yang diberikan lebih efisien.

Tabel 6. Pengaruh tunggal antara pupuk kandang dan zeolite pada KTK tanah

\begin{tabular}{lc}
\hline \multicolumn{1}{c}{ Perlakuan } & Rerata KTK tanah \\
\hline Pengaruh tunggal pupuk kandang & \\
$\mathrm{A}_{0}=$ tanpa pupuk kandang & $10,22 \mathrm{~b}$ \\
$\mathrm{~A}_{1}=200$ g pupuk kandang ayam & $13,01 \mathrm{a}$ \\
$\mathrm{A}_{2}=200 \mathrm{~g}$ pupuk kandang kambing & $12,12 \mathrm{a}$ \\
$\mathrm{BNT}=6,59$ & \\
\hline Pengaruh tunggal zeolite & \\
$\mathrm{Z}_{0}=$ tanpa zeolite & $10,61 \mathrm{~b}$ \\
$\mathrm{Z}_{1}=13 \mathrm{~g}$ zeolite dengan ukuran 30 mesh & $14,68 \mathrm{a}$ \\
$\mathrm{Z}_{2}=13 \mathrm{~g}$ zeolite dengan ukuran 16 mesh & $10,05 \mathrm{~b}$ \\
$\mathrm{BNT}=6,59$ & \\
\hline
\end{tabular}

Keterangan: Nilai rata-rata yang diikuti oleh huruf yang sama pada kolom yang sama menunjukkan tidak berbeda nyata dengan uji BNT pada taraf 5\%

Berdasarkan Tabel 6 bahwa pada perlakuan $Z_{1}$ menunjukan pengaruh nyata terhadap $Z_{0}$ dan $\mathrm{Z}_{2}$. Hal ini diduga karena semakin kecil tingkat kehalusan zeolite maka akan semakin cepat dalam penyerapan, sehingga bahan tanaman tersebut lebih mudah menyerap tanaman pada zeolite bertekstur halus. Sesuai dengan pernyataan Dewi (1997), semakin kecil ukuran butir zeolite akan memperbesar luas permukaan butir, sehingga kesempatan kontak antara larutan dengan zeolit semakin efektif. Menurut Harjowigeno (2002), KTK tanah berbanding lurus dengan jumlah butir liat. Semakin tinggi jumlah liat suatu jenis tanah yang sama, KTK juga bertambah besar. Makin 
halus tekstur tanah makin besar pula jumlah koloid liat dan koloid organiknya, sehingga KTK juga makin besar.

\section{KESIMPULAN}

Berdasarkan hasil penelitian dapat disimpulkan bahwa pemberian pupuk kandang tidak menunjukan pengaruh yang nyata selama 21 MST pada pertumbuhan bibit seperti tinggi tanaman, diameter batang, dan jumlah daun, namun berpengaruh nyata terhadap $\mathrm{pH}$ dan KTK tanah pada perlakuan pupuk kandang ayam. Sedangkan tingkat kehalusan zeolite tidak mempengaruhi tinggi tanaman, diameter batang, jumlah daun, dan $\mathrm{pH}$ tanah, namun berpengaruh terhadap KTK tanah dengan ukuran 16 mesh. Tidak terjadi interaksi antara jenis pupuk kandang dengan ukuran kehalusan zeolite.

\section{DAFTAR PUSTAKA}

Dariah, A. (2007). Bahan Pembenah Tanah, Prospek dan Kendala Pemanfaatannya. Balai Penelitian Tanah, Balai Besar Litbang Sumberdaya Lahan Pertanian. Departemen Pertanian.

Dewi, S. \& Suyitno. (1997). Pengaruh Ukuran Butir Zeolit Pada Koefisien Perpindahan Massa Stronsium Dalam Proses Pertukaran Ion Dalam Limbah Radioaktif. Pusat Teknologi Pengolahan limbah Radioaktif. Jurnal rosiding Presentasi llmiah Daur Bahan Bakar Nuklir III ISSN 1410-1998.

Gardner, P. F., Pearee, \& Mitchell. (1991). Fisiologi Tanaman Budidaya. Universitas Indonesia Press. Jakarta.

Harjadi, S.S. (1996). Pengantar Agronomi. Gramedia Pustaka Utama. Jakarta.

Hardjowigeno, \& Sarwono, H. (2002). Ilmu Tanah. Akademika Pressindo. Jakarta

Juarsah, I. (2016). Pemanfaatan Zeolit dan Dolomit sebagai Pembenah untuk Meningkatkan Efisiensi Pemupukan pada Lahan Sawah. Jurnal Agro, 3(1), 10-19.

Pujiastuti, P., \& Erwan, A. S. (2017). Pengaruh Ukuran Zeolite dan Penambahan NaEDTA pada Penyerapan Logam Zn dalam Limbah Elektroplanting. Jurnal pengolahan sumber daya alam terbarukan, ISSN : 19780427.

Purba, S. T. Z., Damanik, M. M. B, \& Lubis, K. S. (2017). Dampak Pemberian Pupuk TSP dan Pupuk Kandang Ayam Terhadap Ketersediaan dan Serapan Fosfor Serta Pertumbuhan Tanaman Jagung Pada Tanah Inceptisol Kwala Bekala. Jurnal Agroekoteknologi FP USU EISSN No. 2337- 6597 Vol.5.No.3, Juli 2017 (81): 638- 643.

Soemartono. (1990). Genetika Kuantitaif dan Biologi Molekuler. PAU-UGM. Yogyakarta

Subhan, \& Rizwan (2008). Pengaruh Pupuk Kandang Terhadap Produksi Mentimun (Cucumis sativus L.). Hlm 15-24.

Sutejo, M. M., \& Kartasapoetra. (1990). Pupuk dan Cara Pemupukan. Rineka Cipta. Jakarta.

Suwardi. (2002). Pemanfaatan Zeolit untuk Meningkatkan Produksi Tanaman Pangan, Peternakan 
dan Perikanan. Makalah disampaikan pada seminar pemanfaatan zeolit, pertanian organik dan vermikompos dalam menunjang pertanian berkelanjutan. Diselenggarakan Himpunan Mahasiswa Ilmu Tanah Jurusan Tanah Fakultas Pertanian Institut Pertanian Bogor. 12 Mei 2002. Institut Pertanian Bogor. Bogor.

Wahyudi, T., \& Rahardjo, P. (2008). Panduan Lengkap Kakao. Manajemen Agribisnis dari Hulu Hingga Hilir. Penebar Swadaya. Depok. 